\title{
HUBUNGAN ANTARA PRESTASI BELAJAR SISWA DI KELAS DENGAN KEMAMPUAN PRAKTEK SISWA TEKNIK FURNITURE DI SMKN 4 JAKARTA
}

\author{
Febrianto Juwelsdi ${ }^{1}$, Santoso Sri Handoyo ${ }^{2 *}$, Amos Neolaka ${ }^{3^{*}}$ \\ ${ }^{1}$ Alumni Pendidikan Teknik Bangunan, FT UNJ,Jakarta, Indonesia. \\ 2 Pendidikan Teknik Bangunan, FT UNJ, Jakarta, Indonesia. \\ ${ }^{3}$ Pendidikan Teknik Bangunan, FT UNJ, Jakarta, Indonesia \\ *Corresponding author: santoso_handoyo@unj.ac.id, aneolaka@unj.ac.id
}

\begin{abstract}
The objectives of this study analyzing the relationship between students learning achievement in the classroom and students of furniture engineering's practice achievement. This study was conducted in SMKN 4 Jakarta, the population of this study were the year XI students which specialized in Furniture Engineering Competences and wood construction engineering, year 2012/2013 which consist of 18 students. The number of the sample is 12 students. The problem which the writer got from this study was that the students learning achievement was in proportion to the practice achievement, dan the opposite

The instrument of this study is a test which is used to know the relation between students' learning achievements in the classroom and the students' practice achievement. The quesioner shows that the data were valid and the reability was high with $r 11=0.8793$, with 30 point of questions (20 multiple choice questions and 10 essay questions). The result of the study showed that students' learning achievements average score was 76.7 and students practice achievement average score was 78.67.

It showed that the practice has a positive relationship (0.942). In other words, students' learning achievement give contributions to the percentage of practice ability. The students have to prepare themselves to be focus to the lesson or material from the teacher and the teacher should prepare the material and better learning method to help the students to be able to receive all the materials.
\end{abstract}

Keywords: Students achievement in classroom, students practice achievement, correlative descriptive analitycal study 


\section{PENDAHULUAN}

Hal-hal yang mempengaruhi proses dan hasil belajar pun harus diketahui guru dalam menentukan metode atau teknik belajar di SMK yang nantinya akan dipersiapkan langsung untuk bekerja sesuai dengan bidang tertentu. Oleh karena itu seharusnya dipengaruhi pula oleh metode mengajar yang digunakan guru baik dari penerapan belajar maupun suasana lingkungan belajarnya. Selain itu dalam proses belajar mengajar di SMK, perlu adanya keseimbangan dalam proses mengajar baik di kelas maupun di luar kelas (pada saat praktek).

Berdasarkan hasil ujian siswa di Sekolah Menengah Kejuruan 4 Jakarta Utara kelas XI Jurusan Teknik Furniture, nilai standar minimum sekolah adalah 7,5 sedangkan hasil nilai ujian tahun 2011-2013 menunjukkan bahwa nilai yang diperoleh siswa bervariasi. Pada tahun ajaran 2011-2013 sekitar 30\% nilai ujian tertulis siswa SMKN 4 berada dibawah standard minimum sekolah sedangkan $80 \%$ nilai ujian prakteknya berada di atas standard minimum sekolah. Sebaliknya, sekitar $70 \%$ nilai ujian tertulis siswa SMKN 4 berada di atas standard minimum sekolah dan sekitar $80 \%$ nilai ujian prakteknya berada dibawah standard minimum sekolah. Begitu seterusnya untuk materi maupun praktek yang dilakukan.

Melalui kondisi di atas muncul beberapa pertanyaan mengenai sejauh mana hubungan antara prestasi belajar siswa di kelas dengan kemampuan praktek siswa serta bagamaina cara penerapan pendidik agar prestasi belajar siswa dikelas dengan kemampuan praktek dapat dilakukan secara seimbang, dan apakah suasana / kondisi kelas dan workshop dapat mempengaruhi kemampuan prestasi belajar siswa. Dengan melihat dari uraian latar belakang pemikiran, maka penulis tertarik untuk meneliti "Hubungan antara Prestasi Belajar Siswa di Kelas Dengan Kemampuan Praktek Siswa Teknik Furniture di SMKN 4 Jakarta "

\section{METODE PENELITIAN}

Tujuan penelitian secara operasional adalah untuk mengetahui terdapatnya hubungan antara prestasi belajar siswa dikelas dengan kemampuan praktek siswa pada saat praktek di SMKN 4 Jakarta. Penelitian ini diklasifikasikan dalam penelitian kuantitatif deskriptif korelatif, dimana penelitian ini bertujuan untuk menjelaskan, meringkas berbagai kondisi, berbagai situasi atau berbagai variabel yang timbul di masyarakat yang menjadi objek penelitian itu berdasarkan apa yang terjadi dan mencari hubungan antar variabel yang diteliti (hubungan antara prestasi belajar siswa teknik furniture di kelas dengan prestasi belajar siswa pada saat praktek.).

Tempat penelitian ini dilakukan di SMKN 4 Jakarta Jurusan Teknik Furniture. Waktu penelitian dilaksanakan selama bulan Juni dan Juli tahun akademik 2012 - 2013.

Metode penelitian adalah metode survei dengan pendekatan korelasional. Metode merupakan cara yang dilakukan seseorang dalam mencapai tujuan. Sedangkan metode penelitian adalah cara yang digunakan peneliti dalam pengumpulan data penelitian (Suharsimi 
Arikunto, 1998:151). Metode penelitian yang digunakan dalam penelitian ini adalah metode deskriptif yang bersifat korelasional. Metode penelitian deskriptif adalah jenis penelitian yang memberikan gambaran atau uraian atas suatu keadaan sejelas mungkin, tanpa adanya perlakuan. Sedangkan menurut Ali (1992:120) tentang pengertian metode deskriptif, yaitu: suatu metode penelitian yang digunakan untuk berupaya memecahkan atau menjawab permasalahan yang sedang dihadapipada situasi sekarang , dengan tujuan utama untuk membuat gambaran tentang suatu keadaan secara objektif dalam suatu deskriptif situasi.

Menurut Surakhmad, diacu dalam Sudjana (1990:140) metode deskriptif mempunyai ciri yaitu:

1. Memusatkan diri pada pemecahan masalah yang ada pada masa sekarang, pada masalah-masalah yang aktual.

2. Data yang dikumpulkan mula-mula disusun, dijelaskan kemudian dianalisa (karena iti metode ini disebut metode analitik).

Menurut Arikunto $S$ tujuan penelitian korelasional untuk mengemukakan ada atau tidaknya hubungan itu. Kesimpulan yang di dapat dari metode penelitian deskriptif secara umum hanya mendeskripsikan variabel yang diteliti, menghubungkan variable yang satu dengan yang lain, membandingkan antara suatu gejala dengan gejala yang lain, serta menghubungkan peristiwa dengan gejala yang mungkin timbul. Metode ini sejalan dengan maksud penelitian, yaitu untuk melihat hubungan antara suatu variabel dengan variabel lain. Menurut Sudjana (2005:77), "penelitian korelasional bertujuan untuk mengemukakan ada tidaknya hubungan antara dua variabel atau lebih dan aabila ada, seberapa besar derajat hubungannnya serta berarti tidaknya hubungan itu". Metode korelasional yang digunakan pada penelitian ini bertujuan untuk mengetahui ada tidaknya hubungan antara prestasi belajar siswa di kelas dengan prestasi belajar siswa pada saat praktek. Dalam penelitian ini, peneliti menggunakan kelas XI TF 2012/2013 SMKN 4 Jakarta.

Populasi adalah keseluruhan obyek penelitian (Arikunto, 1998: 115). Adapun yang menjadi populasi dalam penelitian ini adalah keseluruhan siswa Jurusan Teknik Furniture di SMKN 4 Jakarta sejumlah 30 siswa yang terdiri dari siswa kelas XI dan XII 2012-2013.

Sampel adalah sifat-sifat atau karakteristik dari sekelompok subjek, gejala atau objek. Sifat dan karakteristik tersebut melalui instrument yang telah dipilih dan dipersiapkan oleh peneliti (Sudjana, 1990:71). Sampel yang digunakan dalam penelitian ini adalah seluruh siswa kelas XI 2012 - 2013 Jurusan Teknik Furniture sejumlah 18 siswa. Seluruh siswa ini diambil tahun akademik 2012-2013.

Teknik analisis data dalam penelitian ini menggunakan uji korelasi dan regresi. Sebelum menggunakan uji korelasi dilakukan uji persyaratan analisi, yaitu normalitas dan linearitas. Uji korelasi bertujuan untuk mengetahui arah dan kekuatan hubungan antara variabel numerik dan numerik, Koefisien Korelasi Pearson ( $r$ ). 


\section{HASIL DAN PEMBAHASAN}

Untuk menguji hipotesis penelitian atau mengetahui ada tidaknya hubungan antara variabel bebas yaitu prestasi belajar dengan variabel terikat yaitu kemampuan praktek dilakukan menggunakan uji t dengan kriteria thitung $>t_{\text {tabel }}$. Berdasarkan perhitungan diperoleh thitung sebesar 133,38, sedangkan ttabel dengan taraf kesalahan $5 \%$ uji dua pihak dan derajat kebebasan $(\mathrm{dk})=\mathrm{n}-2=18-2=16$ maka diperoleh ttabel sebesar 2,101. Dengan demikian $t_{\text {titung }}>t_{\text {tabel }}$ atau 133,38 $>2,101$ artinya tolak Ho dan terima Ha. Hasil Penelitian adalah terdapat hubungan antara prestasi belajar dengan kemampuan praktek (hasil perhitungan terdapat pada lampiran15). Untuk lebih jelas hasil pengujian hipotesi dapat dilihat di tabel 1.

Tabel 1. Uji Hipotesis Penelitian

\begin{tabular}{|c|c|c|c|c|}
\hline No & $\mathbf{t}_{\text {hitung }}$ & $\mathbf{t}_{\text {tabel }}$ & Keputusan & Keterangan \\
\hline 1. & 133.38 & 2,101 & $\begin{array}{c}\text { Tolak Ho, } \\
\text { Terima Ha }\end{array}$ & $\begin{array}{c}\text { Terdapat Hubungan Antara } \\
\text { Prestasi Belajar Dengan } \\
\text { Kemampuan Praktek }\end{array}$ \\
\hline
\end{tabular}

Setelah diketahui adanya hubungan antara prestasi belajar dengan kemampuan praktek, selanjutnya adalah menentukan kriteria hubungan yang dinotasikan dengan koefisien korelasi (rxy). Untuk menentukan koefisien korelasi tersebut dilakukan perhitungan manual dengan Rumus Product Momen.

Dari hasil perhitungan menggunakan perhitungan manual didapat koefisien korelasi (rxy) sebesar 0,887. Dengan nilai koefisien korelasi tersebut dapat diinterpretasikan bahwa hubungan prestasi belajar dengan kemampuan praktek tergolong tinggi.

Besarnya hubungan prestasi belajar dengan kemampuan praktek ditentukan oleh koefisien determinasi (rxy2). Berdasarkan perhitungan diperoleh koefisien determinasi (rxy2) yaitu 0,887 atau $88,7 \%$. Ini berarti bahwa meningkat atau menurunkan kemampuan praktek $88,7 \%$ dapat dijelaskan oleh prestasi belajar melalui hubungan linear yang persamaannya adalah $\hat{Y}=56,646+0,288 x$ atau dengan kata lain kontribusi prestasi belajar terhadap kemampuan praktek sebesar $88,7 \%$, dan sisanya sebesar $11.3 \%$ ditentukan oleh faktor lain.

Berdasarkan analisis dan hasil pengujian hipotesis yang telah dilakukan menunjukkan bahwa hipotesis yang diajukan dalam penelitian ini diterima yaitu terdapat hubungan antara prestasi belajar terhadap kemampuan praktek pada siswa SMKN 4 Jakarta. Hal tersebut ditunjukkan dengan nilai thitung sebesar 133,38 lebih besar dari pada ttabel sebesar 2,101pada taraf kesalahan (alpha) sebesar 0,05.

Pengujian hipotesis ini menggambarkan bahwa prestasi belajar akan mempengaruhi kemampuan praktek. Siswa yang memiliki 
prestasi belajar akan mampu melakukan kegiatan pembelajarannya yang didasarkan atas keinginannya sendiri. Bentuk kegiatan pembelajaran tersebut mulai dari tahap merencanakan, melaksanakan, menyelesaikan, dan mengevaluasi.

Pola hubungan antara variabel prestasi belajar dengan variabel kemampuan praktek ini dinyatakan dengan persamaan regresi $\hat{Y}=$ $56,646+0,288 x$. Persamaan ini memberikan informasi bahwa setiap perubahan baik itu peningkatan maupun penurunan satu satuan prestasi belajar akan diikuti dengan perubahan baik peningkatan maupun penurunan pada kemampuan praktek sebesar 0,288 satuan pada konstanta 56,646.

Hasil analisis korelasi/hubungan antara prestasi belajar dengan kemampuan praktek diperoleh koefisien korelasi (rxy) sebesar 0,877. Nilai ini memberikan pengertian bahwa prestasi belajar dengan kemampuan praktek memiliki hubungan yang tergolong tinggi. Hal tersebut juga menggambarkan bahwa semakin tinggi prestasi belajar siswa maka semakin tinggi pula kemampuan praktek, begitu pula sebaliknya semakin rendah prestasi belajar siswa maka semakin rendah pula kemampuan prakteknya.

Besarnya kemampuan praktek ditentukan oleh variabel prestasi belajar. Besarnya kontribusi prestasi belajar yang berpengaruh terhadap kemampuan praktek dapat diperoleh dengan cara mengkuadratkan koefisien korelasi (rxy) kemudian dikali 100\%. Hasil kuadrat koefisien korelasi tersebut dinamakan koefisien determinasi (rxy2). Besarnya koefisien determinasi (rxy2) dalam penelitian ini adalah sebesar $88,7 \%$.

Koefisien determinasi sebesar $88,7 \%$ menggambarkan bahwa prestasi belajar memberikan kontribusi sebesar $88,7 \%$ terhadap kemampuan praktek. Hal ini pun dapat dilihat dari memanfaatkan fasilitas perpustakaan, belajar mandiri dirumah, diskusi dengan teman, memanfaatkan sumber belajar, mengerjakan latihan tatap muka, memiliki bahan ajar, mengukur kemampuan dari hasil belajar tatap muka, mengukur kemampuan dari hasil belajar ujian, metode belajar yang digunakan, media belajar yang digunakan, alokasi waktu belajar, kesiapan dalam belajar, daya tahan dalam belajar, memanfaatkan waktu belajar, lama belajar, konsenterasi dalam belajar, membaca pendahuluan buku, membaca uraian materi, dan mengerjakan latihan soal pada buku. Adapun sisa persentase koefisien determinasi sebesar $11,3 \%$ yang berkontribusi pada kemampuan praktek ditentukan oleh faktor lain.

\section{KESIMPULAN}

Berdasarkan hasil penelitian maka deskripsi, analisis, dan interpretasi data yang telah diuraikan pada bab-bab sebelumnya, dapat ditarik kesimpulan sebagai berikut:

1. Prestasi belajar dengan kemampuan praktek memiliki hubungan yang sangat tinggi. Prestasi belajar yang ada pada siswa memberikan kontribusi terhadap tinggi rendahnya kemampuan praktek, artinya semakin tinggi prestasi belajar 
siswa, maka semakin tinggi pula kemampuan praktek.

2. Metode pembelajaran yang digunakan guru pun dapat mempengaruhi hasil belajar siswa, terutama metode pembelajaran yang nantinya akan dipergunakan di dalam pembelajaran di kelas maupun pembelajaran pada saat praktek.

3. Agar mendapatkan hasil praktek yang baik, maka sarana dan prasarana pun harus mendukung, supaya dalam mengerjakan praktek tersebut siswa dapat mengerjakan secara maksimal.

\section{Implikasi}

Sebagai suatu penelitian yang telah dilakukan di lingkungan pendidikan maka hasil penelitian mempunyai implikasi dalam bidang pendidikan, sehubungan dengan hal tersebut maka implikasinya sebagai berikut :

Berdasarkan pada hasil penelitian bahwa Prestasi Belajar Siswa memberikan kontribusi yang berarti terhadap Kemampuan Praktek. Selama ini masalah Prestasi Belajar dan hasil praktek kurang mendapat perhatian yang serius dari pihak guru. Maka dalam mengatasi masalah tersebut, diperlukan adanya usaha dan upaya dari pihak Guru dengan cara mengadakan perbaikan pada Prestasi Belajar melalui metode pengajaran dan mengevaluasi setiap materi yang disampaikan dengan melakukan tes agar meningkatkan dan mendapatkan hasil yang baik antara kemampuan praktek dan prestasi belajar.

\section{Saran}

Berdasarkan kesimpulan di atas dapat dikemukakan saran-saran sebagai berikut :

1. Belajar di rumah jelas sangat berbeda dengan belajar di tingkat sekolah. Perlu adanya kesadaran yang tinggi atas diri siswa dan mampu memahami karakteristik dari setiap mata pelajaran yang ditempuh.

2. Dengan mengetahui gambaran prestasi belajar dan kemampuan praktek siswa, maka seyogyanya sekolah menyediakan sarana dan prasana yang baik agar siswa dapat melakukan stiap pembelajaran secara maksimal.

3. Test praktek yang diberikan oleh guru sebaiknya diterapkan dahulu oleh guru agar murid dapat memilki pandangan di dalam memulai praktek.

4. Para pendidik dalam hal ini guru, disamping melaksanakan tugas sebagai pendidik hendaknya memperhatikan metode pembelajaran dan media pembelajaran sehingga mata pelajaran yang nantinya di terapkan di praktek dapat dilakukan dengan maksimal dan dapat memotivasi siswa untuk belajar lebih sungguh-sungguh sehingga prestasi belajar siswa dapat meningkat dan mencapai kemampuan praktek yang lebih baik lagi.

\section{DAFTAR PUSTAKA}

Andrice, Aifi. dan Sesmiwati. 2011. Jasa Quantity Akademik, bidang. 2007. Buku Pedoman Akademik 2009-2010. UNJ Jakarta. 
Akademik, bidang. 2007. Buku Statistik. UNJ Jakarta.

Akhmadsudrajat. 2011. Gaya Belajar Siswa. http://akhmadsudrajat.wordpress. com/2011/12/07/gaya-belajar-siswamenurut-david-kolb/. [Diunduh: 5 Februari 2013, Jam 04.00 WIB]

Ansori, Muhammad. 2002: 36. Proses Belajar dan Hasil Belajar. Yogyakarta. Universitas Negeri Yogyakarta.

Arikunto, Suharsimi. 1997. Prosedur Penelitian. Jakarta, Rineka Cipta.

Arikunto, Suharsimi. 1998. Dasar-Dasar Metodelogi Penelitian. Jakarta: Gelar

Arikunto, Suharsimi. 2002. Prosedur Penelitian Suatu Pendekatan Praktek. Jakarta: Rineka Cipta.

Ali, Muhammad. 1992. Guru dalam Proses Belajar Mengajar. Bandung. CV. Sinar Baru

Dalih, S.A. dan O. Sutiarna. 1978. Petunjuk Pengerjaan Kayu. Jakarta: Dorektorat Pendidikan Menengah Kejuruan Departemen Pendidikan dan Kebudayaan. Djuharis Rasul dan Prawoto. 1998. Gambar Teknik Untuk Sekolah Menengah Kejuruan Kelompok Teknologi dan Industri Jurusan Bangunan Berdasarkan Kurikulum SMK 1994. Bandung Angkasa.

George Love. "Teori dan Praktek -Kerja Kayu". Alih Bahasa: E. Diraatmadja. Jakarta: Penerbit Erlangga, 1985.

Hoeve, Van. Ensiklopedia Indonesia N/Z. Bandung. Redaksi. http://skarianty. blogspot.com/2011/03/10-pengertianteori-menurut-para-ahli.html [Diunduh :14 April 2013, Jam 20:22 WIB]

Hudori, Abdullah. 2006. Hubungan antara hasil belajar di kelas dengan hasil praktek. Skripsi. Universitas Negeri Yogyakarta
Martono, Budi dkk. 2004. Teknik Perkayuan / Parabot Kayu untuk SMK. Jakarta: Pustaka Sinar Harapan

Roestiyah N.K 1989. Didaktik metodik. Jakarta : Bumi Aksara

Sagitasari, Dewi. 2010. Hubungan Antara Kreativitas Dan Gaya Belajar Dengan Prestasi Belajar. Skripsi. Universitas Negeri Yogyakarta.

Slameto 1995. Belajar dan faktor-faktor yang mempengaruhinya. Jakarta: Rineka Cipta

Sudjana, Nana. 1990. Penilaian Hasil Belajar Proses Belajar Mengajar. Bandung: PT. Remaja Rosdikarya

Sudjana, Nana. 2005. Metoda Statistika. Bandung: PT Tarsito Bandung

Sugandi, Achmad, dkk. 2004. Teori Pembelajaran. Semarang:UPT MKK UNNES.

Sugiyono. 2007. Metode Penelitian Pendidikan. Bandung: Alfabeta.

Sunaryo, Agus. 1995. Peningkatan Produktivitas Bagian Finishing Melalui Aspek Aplikasi. Semarang: Pusat Pengembangan \& Pelatihan Industri Kayu (PPPIK-PIKA).

Sunaryo, Agus. 1997. Reka Oles Mebel Kayu, Yogyakarta: Penerbit Kanisius.

Trianto, Edi. 2008. Pengaruh Fasilitas dan Motivasi Belajar Siswa Terhadap Prestasi Siswa Kelas II. Universitas Sarjanawiyata Taman siswa.

Undang-Undang Republik Indonesia Pasal 3 No 20 tahun 2003

Uno, Hamzah. 2001. Pengembangan Instrumen Untuk Penelitian. Jakarta: Delima Press.

Yamin, dkk. 1999. Sambungan dan Hubungan Kayu . Jakarta : Direktorat Jendral Pembinaan Kelembagaan Agam Islam, 
Direktorat Pembinaan Perguruan Agama Islam, Departemen Agama

Universitas Negeri Jakarta. 2011. Pedoman Akademik 2011/2012. Jakarta: Universitas Negeri Jakarta. 